\title{
Öğretmen Adaylarının Bilimsel Araştırma Öz Yeterlik Algılarının İkili Karşılaştırmalı Yargılar Yöntemiyle Belirlenmesi
}

\section{Determining Prospective Teachers' Self-Efficacy Perception on Scientific Skills Via Pair-Wise Comparison Method}

\author{
Arife KART* Selahattin GELBAL**
}

\begin{abstract}
Öz
$\mathrm{Bu}$ araştırmanın amacı, öğretmen adaylarının bilimsel araştırma becerilerine ilişkin öz yeterlik algıları üzerinde etkili olduğu düşünülen faktörleri, ikili karşılaştırmalar kanunuyla ölçekleyerek belirlemektir. Araştırma, 20122013 eğitim-öğretim yılında, Ankara ilinde bulunan ve bir tanesi devlet üniversitesi ve diğeri vakıf üniversitesi olmak üzere iki üniversite kapsamında gerçekleştirilmiştir. Araştırmanın verileri bilimsel araştırma yöntemleri dersi almış toplam 180 öğretmen adayından elde edilmiştir. Elde edilen bulgulara göre, bilimsel araştırma becerilerine ilişkin öğretmen adaylarının; öz yeterlik algılarının veri toplama ve raporlaştırma uyarıcılarının en yüksek yeterlik düzeyine sahip olduğu ancak veri analizi ve değişkenleri belirleme uyarıcılarının ise en düşük yeterliğe sahip olduğu sonucuna ulaşılmıştır.
\end{abstract}

Anahtar Kelimeler: Bilimsel araştırma becerileri, öz yeterlik algıları, ölçekleme, ikili karşılaştırmalar yöntemi

\begin{abstract}
The aim of this study is to determine the factors which are considered to be effective in self efficacy perceptions relating to scientific research skills of preservice teachers by using scalling through the pair-wise comparison methods. The study was carried out in fall 2012-2013 at Ankara University and Başkent University. The data of the study was collected from 180 preservice teachers who took scientific research methods course. According to the data obtained from the study, preservice teachers relating to scientific research skills, have the highest level of competence in self-efficacy perceptions in terms of data collection and reporting features, although they have the lowest competence in the analysis of data and identifying variables.
\end{abstract}

Keywords: Scientific research skills, self efficacy perceptions, scaling, pair-wise comparison methods

\section{GİRIŞ}

Bireyler, merak ettikleri bir konu hakkında bilgi edinmek ya da kaygı duydukları bir sorunu gidermek amacıyla araştırma yaparlar. Böylece birey, aktif olarak araştırma sürecinin içinde yer alır. Araştırma süreci ise problemin belirlenmesi ile başlar. Araştırma, problemlere güvenilir çözümler aramak amacı ile sistemli süreçler çerçevesinde planlı ve sistemli olarak, verilerin toplanmas1, verilerin analiz edilmesi, yorumlanarak değerlendirilmesi ve rapor edilmesi sürecidir (Kaptan, 1995 ve Karasar, 2002). Bilimsel araştırmaların yapılabilmesi için öncelikle bilimsel tutum ve anlayışların kazanılması ve geliştirilmesi gerekir. Ancak bu durum bilgi, beceri ve tutumların entegrasyonunun sağlanması ile mümkün olmaktadır (Saracaloğlu, Varol ve Ercan, 2003). Araştırma becerilerine ilişkin tutumlar, üniversitelere ve öğrenim görülen alana göre değişmektedir (Büyüköztürk, 1996).

Araştırmacı özelliklere sahip öğretmenler, hem kendilerinin hem de öğrencilerinin bireysel gelişimine ve araştırma becerilerine katkı sağlar (Godson, 1994). Birey araştırma etkinliklerine aktif olarak katıldığı takdirde araştırma becerisini kazanır ve araştırma yeterliğine sahip olur. Araştırma yeterlikleri ise araştırma etkinlikleri ile pekişmektedir ve bu sayede öğretmenler araştırma becerilerine ilişkin yüksek öz yeterlik algılarına sahip olur.

\footnotetext{
* Arş. Gör., Başkent Üniversitesi, Eğitim Fakültesi, Ankara-Türkiye, e-posta: arife@ baskent.edu.tr

** Prof. Dr., Hacettepe Üniversitesi, Eğitim Fakültesi, Ankara-Türkiye, e-posta: gelbal@ hacettepe.edu.tr
} 
Bandura (1997), öz yeterlik algısını; bireyin olası durumlar ile başa çıkabilmesi için gerekli olan görevlerin üstesinden gelme durumu olarak tanımlarken diğer taraftan Guskey ve Passaro (1994) ise öz yeterlik algısını bireyin kendi yeteneklerine olan inancının ve güvenmesi olarak tanımlamışlardır.

Bilimsel düşünme, bireyin bir problem durumunda bu problemin çözümüne yönelik olarak verdiği bilimsel, mantıklı ve tutarlı tepkilerdir. Bilimsel düşünme süreci, belli bir sorunun çözümüne yönelik hipotezler kurabilme ve bu hipotezlerin doğru olup olmadığını sistematik bir yolla test etme süreci olarak değerlendirilmektedir (Gündoğdu, 2001). Stuessy'e göre (1984) bilimsel düşünme, bilimsel araştırma sürecinde bireyin, herhangi bir sorunun çözümüne yönelik olarak uyguladığı tutarlı, mantıklı düşünmedir. Geban (1990), bilimsel işlem becerilerinin temel boyutları olarak, değişkenlerin belirlenmesi, hipotezlerin belirlenmesi ve ifade edilmesi, işevuruk tanım yapabilme ve yorumlanması becerilerini siralamaktadir.

Toplumsal yapının bir parçası olan cinsiyet farklılıkları, insan yaşamında oldukça yaygın olarak gözlenmiştir. Dolayısıyla cinsiyet farkı bireylerin; akademik, sosyal ve psikolojik yaşantılarını etkileyebilir (Gündoğdu, 2001).

Yapılan pek çok çalışmada, araştırma yöntemleri dersi alma durumunun öğretmenlerin, kendi sınıflarında daha çok araştırma yapmalarını sağladığına, araştırma öz yeterlik düzeylerini arttırdığına, araştırma yapma konusunda yüksek öz yeterliğe sahip olan öğretmenlerin gelecekte araştırmalara katılma konusunda hem çok ilgili olduklarına hem de araştırma üretiminin yüksek olduğuna ve bununla birlikte araştırma kaygılarının azaldığ sonucuna ulaşılmıştır (Green ve Kvidhal, 1990; Phillips ve Russell, 1994; Bieschke, Bishop ve Garcia, 1996; Unrau ve Beck, 2004). Diğer yandan Büyüköztürk (1996) tarafından yapılan bir araştırmada, üniversite öğrencilerinin araştırma üretimine yönelik tutumlarının olumsuz olduğu sonucuna ulaşılmıştır. Karagül (1996), tarafından yapılan bir çalışmada ise bireylerin araştırma yeterliğine sahip olma düzeyinin yetersiz olduğu sonucuna varılmıştır. İlköğretim okulu öğretmenlerinin araştırma yeterliklerini önemli gördüklerini ancak bu yeterliklere yeterince sahip olmadıklarını belirlemiştir (Büyüköztürk, 1999).

Yukarıda sözü geçen araştırmalar ele alındığında bireylerin bir yandan aktif olarak araştırma sürecinin içinde yer almanın onların araştırma yeterliğini geliştirdiği ve araştırma kaygılarını azalttığ olduğu görülmektedir. Bu durumda araştırma yeterliğine ilişkin, algılanan ve gerçek büyüklük arasındaki farkın bilinmesine ihtiyaç vardır. Ölçülmek istenen niteliklerin ya da herhangi bir değişkenin gerçek büyüklüğü ile algılanan büyüklük arasındaki farktan ya da bağıntılardan ortaya çıkan ölçeklemedeki temel amaç, gözleme dayalı ampirik ilişkilerden, kurallara dayalı formel ilişkilere geçişin yöntemlerini ortaya koymaktır (Turgut ve Baykul, 1992). Bu nedenle ölçme sürecinde ölçekleme, nitel ayrımları gösteren gözlemlerden nicel ayrımları gösteren ölçülere geçişte önemli bir halka olarak görülmektedir (Anıl ve Güler, 2006). Ölçekleme, denek tepkilerine ve yargıcı kararlarına dayalı yaklaşımlar olmak üzere iki grupta toplanmaktadır. Her bir cevaplayıcının maddelere verdiği tepkilere dayalı olarak bireyleri ölçek üzerinde farklı bir yere yerleştirmeye odaklanan (Crocker ve Algina, 1986) ve cevaplayıcı (denek) merkezli olan denek tepkilerine dayalı yaklaşımda cevaplar ölçeklenir (Torgerson, 1958). Yargıcı kararlarına dayalı yaklaşım ise, uyarıcıları uzman ya da bilirkişi yargılarına göre sıralama, sınıflama, aralık, oran ölçeğinde belirli bir boyutta ölçeklemeyi kapsar (Stevens, 1946). Yarg1 yaklaşımına dayanan ikili karşılaştırmalar kanununda ise amaç, $\mathrm{N}$ sayıda gözlemciden verilen her bir uyarıcıyı ikişer ikişer karşılaştırarak hangi uyarıcının diğerinden daha büyük olduğunu belirlemektir (Guilford, 1954). 
Her öğretmen adayı bireysel olarak araştırma yapabilme becerisine sahip olmalıdır. Araştırmacı bir kimliğe sahip olan öğretmenler sorgulayıcı olmakla birlikte araştırma yapma becerisini geliştirmiş olacaklardır. Bir başka deyişle, araştırma ve sorgulama becerisi gelişmiş öğretmenler, öğretmenlik mesleğini icra ederlerken öğrencilerinin de araştırma ve sorgulama becerilerine katkı sağlayacaklardır. Ayrıca bir öğretmen her durumda öğrenciliği bitmeyen bir süreç içindedir. $\mathrm{Bu}$ nedenle bir öğretmen adayının alanda mesleki ve akademik anlamda bilimsel gelişmelere duyarlı olması ve bu gelişmeleri yakından takip etmesi büyük önem taşımaktadır. Dolayısıyla, öğretmen adaylarının lisans eğitimleri süresince edindikleri araştırma becerilerinin ne düzeyde olduğunun araştırılması ve bu becerilere yönelik öğretmen adaylarının öz yeterlik algılarının belirlenmesi önemli ve gerekli görülmektedir. Bu amaç doğrultusunda ölçekleme tekniklerinden "İkili Karşılaştırmalar Kanunu ile V.Hal Denklemi Tam Veri Matrisinden Ölçekleme" yöntemi kullanılarak öğretmen adaylarının bilimsel araştırma becerilerine ilişkin öz yeterlik algıları araştırılmıştır.

\section{Araştırmanın Amacı}

Araştırmanın temel amacı, öğretmen adaylarının bilimsel araştırma becerilerine ilişkin öz yeterlik algılarının ikili karşılaştırmalar kanunu V. Hal denklemi ile tam veri matrisinden ölçekleme yaparak belirlemektir. 2012-2013 eğitim-öğretim yılı güz döneminde devlet üniversitesinde bilimsel araştırma yöntemlerini Sosyal Bilgiler Öğretmenliği Programı öğrencileri ile Rehberlik ve Psikolojik Danışmanlık Programı öğrencileri almakta iken diğer taraftan vakıf üniversitede Türkçe Öğretmenliği Programı öğrencileri ile İlköğretim Matematik Öğretmenliği öğrencileri bilimsel araştırma yöntemleri dersini almaktadırlar. Dolayısıyla araştırma kapsamı bu öğretmenlik programları ile sınırlandırılmıştır. Öğretmen adaylarının bilimsel araştırma becerilerine ilişkin öz yeterlik algıları; öğrenim görülen program, üniversite türü ve cinsiyet olmak üzere üç değişken ile sınırlandırılmış olup aşağıda yer alan sorulara yanıt aranmıştır. $\mathrm{Bu}$ amaç doğrultusunda bilimsel araştırma becerilerine yönelik öz yeterlik algılarına ilişkin;

1- Rehberlik ve Psikolojik Danışmanlık Programı öğretmen adayları için ölçek değerleri nasıldır?

2- Sosyal Bilgiler Öğretmenliği Programı öğretmen adayları için ölçek değerleri nasildir?

3- Türkçe Öğretmenliği Programı öğretmen adayları için ölçek değerleri nasıldır?

4- Matematik Öğretmenliği Programı öğretmen adayları için ölçek değerleri nasıldır?

5- Devlet üniversitesinde öğrenim gören öğretmen adayları için ölçek değerleri nasıldır?

6- Vakıf üniversitesinde öğrenim gören öğretmen adayları için ölçek değerleri nasıldır?

7- Kadın öğretmen adayları için ölçek değerleri nasıldır?

8- Erkek öğretmen adayları için ölçek değerleri nasıldır?

9- Tüm grup için öğretmen adayları için ölçek değerleri nasıldır?

\section{Araştırmanın Önemi}

Günümüz bilgi çağında her an dünya hızla gelişmekte ve değişmektedir. Bu hızlı gelişmeler çerçevesinde ülkemiz de değişime uyum sağlamak durumundadır. Dolayısıyla bilgi çağında gelişmeleri takip edebilmek için bilimsel çalışmaları izleme becerilerine sahip olunması gerekli görülmektedir. Bilimsel çalışmaları inceleyebilmek ve irdeleyebilmek için ise öncelikle bireylerin araştırma yeterliğine sahip olması ve sorgulama becerilerinin kazanılmış olması büyük önem taşımaktadır. Araştırma ve sorgulama becerilerinin kazanımının önemli bir kısmı ise okullarda ve üniversitelerde gerçekleşmektedir. $\mathrm{Bu}$ nedenle okullarda ve 
üniversitelerde bilimsel çalışmalara ilişkin eğitim sürecinin çok iyi değerlendirilmesi gerekmektedir.

Farklı öğretmenlik programlarında öğrenim gören öğretmen adayları, lisans eğitimlerinde bilimsel araştırma yöntemleri, ölçme ve değerlendirme ile istatistik derslerini almaktadırlar. Bir öğretmen adayının, araştırmacı bir yapıya sahip olunması beklenir. Bu dersler aracılı̆̆ sonuçların yorumlanarak raporlaştırılması gibi kazanımlar edinmektedirler. Ancak kazanımlar sadece bilgi düzeyinde kalmakta ve bir uygulama yapılması durumunda çeşitli sıkıntılarla karşılaşılmakta ve öğretmen adayları kendilerini yetersiz hissetmektedirler.

$\mathrm{Bu}$ kapsamda öğretmen adaylarının bilimsel araştırma becerilerine ilişkin öz yeterlik algılarının ikili karşılaştırmalar yöntemi ile araştırılmasının alana katkı sağlayacağı ve üniversitelerde bilimsel araştırma yöntemleri dersinin bir öğretmen adayı için daha nitelikli düzeylerde kazandırılmasında faydalı olacağı düşünülmektedir.

\section{YÖNTEM}

$\mathrm{Bu}$ çalışma, ikili karşılaştırmalar yöntemi ile ölçekleme yapılarak öğretmen adaylarının bilimsel araştırma becerilerine ilişkin öz yeterlik algılarının belirlenmesine odaklanmıştır. $\mathrm{Bu}$ nedenle örneklem bilgilerinden bir evrene genelleme yapma amac1 güdülmediği için bu çalışma, nicel bir yöntem olmakla birlikte temel bir araştırma modeli niteliğindedir (Karasar, 2002).

\section{Çalışma Grubu}

Araştırma grubunu, 2012-2013 akademik eğitim-öğretim yılı Güz döneminde Ankara Üniversitesi Eğitim Bilimleri Fakültesi Rehberlik ve Psikolojik Danışmanlık Programı (N=51, \%28.33) ve Sosyal Bilgiler Öğretmenliği Programı (N=46, \%25.55) ile Başkent Üniversitesi Eğitim Fakültesi Türkçe Öğretmenliği Programı (N=57, \%31.66) ve İlköğretim Matematik Öğretmenliğgi Programı'nda ( $\mathrm{N}=26, \%$ 14.44) öğrenim gören ve bilimsel araştırma yöntemleri dersi almış toplam 180 öğrenci oluşturmuştur. Amaçli örneklem ile 180 öğrenci araştırmaya gönüllü olarak katılmışlardır. Çalışmaya devlet ve vakıf üniversitelerinde bilimsel araştırma yöntemleri dersini alan öğrenciler dahil edilmiştir.

\section{Veri Toplama Araci}

Bir bilimsel araştırma sürecinde araştırma teknikleri, istatistik, ölçme ve değerlendirme ve bilgisayar alanları; araştırma yeterliklerinin bir bileşenidir (Büyüköztürk ve Köklü, 1999). Bu nedenle ölçme aracının hazırlanmasında problem belirleme, literatür tarama, veri toplama, veri analizi ve raporlaştırma gibi bilimsel araştırma basamakları dikkate alınmıştır. Hem öğrencilere hem de bu dersi veren öğretim üyelerine öğrencilerin bilimsel araştırma yöntemleri konusunda hangi basamaklarda güçlük çektikleri yazılı olarak gerekçeleri ile belirtmeleri istenmiştir. Bu şekilde "problemi belirleme, değişkeni belirleme, literatür tarama, araştırma yöntemini belirleme, veri toplama, veri analizi ve raporlaştırma" değişkenleri, veri toplama aracını oluşturmuştur.

\section{Verilerin Analizi}

$\mathrm{Bu}$ çalışmada her bir öğretmen adayının bilimsel araştırma becerilerine ilişkin yedi niteliği Ikili Karşılaştırmalar Kanunu ile sıralamaları neticesinde öncelikle frekanslar matrisi (F matrisi) oluşturulmuştur. Daha sonra frekanslar matrisinde yer alan her bir hücredeki değer, toplam kişi sayısına $(\mathrm{N})$ bölünerek oranlar matrisi (P oranlar matrisi) elde edilmiştir. Oranlar matrisindeki her bir hücre değerine karşılık gelen standart değerler belirlenerek Z birim 
normal sapmalar matrisi elde edilerek ölçek değerleri hesaplanmıştır. Eğer ölçek değerlerinden bir ya da daha fazla negatif değer var ise en küçük değer sıfira eşitlenerek bir başka ifade ile başlangıç noktası sıfıra taşınarak tüm ölçek değerleri (S) pozitif olacak şekilde ötelenmiştir.

\section{BULGULAR}

$\mathrm{Bu}$ bölümde öğretmenlik programı, üniversite türü ve cinsiyet değişkenleri için öncelikle frekanslar matrisi ve frekanslar matrisine dayalı oranlar matrisi ve Z birim normal sapmalar matrisi ile farklar matrisi ve hata istatistikleri hesaplanmış ve sonuçları aşağıda yorumlanmıştır.

Rehberlik ve Psikolojik Danışmanlık Programı öğretmen adayları için bilimsel araştırma becerilerine yönelik öz yeterlik algılarına ilişkin ölçek değerleri Tablo 1'de verilmiştir.

Tablo 1. Rehberlik ve Psikolojik Danışmanlık Programı Öğretmen Adaylarının Bilimsel Araştırma Becerilerine Yönelik Öz Yeterlik Algılarına İlişkin Ölçek Değerleri

\begin{tabular}{llcc}
\hline Faktörler & Uyarıcılar & Ölçek Sırasi & Ölçek Değeri \\
Problemi Belirleme & U1 & 4 & 0,335 \\
Değişkenleri Belirleme & U2 & 3 & 0,256 \\
Literatür Tarama & U3 & 1 & 0,000 \\
Araştırma Yöntemini Belirleme & U4 & 6 & 0,672 \\
Veri Toplama & U5 & 5 & 0,451 \\
Veri Analizi & U6 & 7 & 1,062 \\
Raporlaştırma & U7 & 2 & 0,235 \\
\hline
\end{tabular}

Tablo 1 incelendiğinde rehberlik ve psikolojik danışmanlık programı öğretmen adaylarının bilimsel araştırma becerilerine yönelik öz yeterlik algılarının literatür tarama uyarıcısının en yüksek ve veri analizi uyarıcısının ise en düşük olduğu görülmektedir. Öğretmen adaylarının bilimsel araştırma becerilerine yönelik öz yeterlik algılarının en yüksek olandan en düşük olana doğru ölçek sıralarının literatür tarama, raporlaştırma, değişkenleri belirleme, problemi belirleme, veri toplama ve veri analizi olduğu sonucuna ulaşılmıştır.

Sosyal Bilgiler Öğretmenliği Programı öğretmen adayları için bilimsel araştırma becerilerine yönelik öz yeterlik algılarına ilişkin ölçek değerleri Tablo 2'de verilmiştir.

Tablo 2. Sosyal Bilgiler Öğretmenliği Programı Öğretmen Adaylarının Bilimsel Araştırma Becerilerine Yönelik Öz Yeterlik Algılarına İlişkin Ölçek Değerleri

\begin{tabular}{lccc}
\hline Faktörler & Uyarıcılar & Ölçek Sırası & Ölçek Değeri \\
Problemi Belirleme & U1 & 4 & 0,357 \\
Değişkenleri Belirleme & U2 & 7 & 0,674 \\
Literatür Tarama & U3 & 3 & 0,321 \\
Araştırma Yöntemini Belirleme & U4 & 5 & 0,379 \\
Veri Toplama & U5 & 2 & 0,038 \\
Veri Analizi & U6 & 6 & 0,448 \\
Raporlaştırma & U7 & 1 & 0,000 \\
\hline
\end{tabular}

Tablo 2 incelendiğinde sosyal bilgiler öğretmenliği programı öğretmen adaylarının bilimsel araştırma becerilerine yönelik öz yeterlik algılarının raporlaştırma uyarıcısının en yüksek ve değişkenleri belirleme uyarıcısının ise en düşük olduğu görülmektedir. Öğretmen adaylarının bilimsel araştırma becerilerine yönelik öz yeterlik algılarının en yüksek olandan 
en düşük olana doğru ölçek sıralarının raporlaştırma, veri toplama, literatür tarama, problemi belirleme, araştırma yöntemini belirleme, veri analizi ve değişkenleri belirleme olduğu sonucuna ulaşılmıştır.

Türkçe Öğretmenliği Programı öğretmen adayları için bilimsel araştırma becerilerine yönelik öz yeterlik algılarına ilişkin ölçek değerleri Tablo 3 'te verilmiştir.

Tablo 3. Türkçe Öğretmenliği Programı Öğretmen Adaylarının Bilimsel Araştırma Becerilerine Yönelik Öz Yeterlik Algılarına İlişkin Ölçek Değerleri

\begin{tabular}{llcl}
\hline Faktörler & Uyarıcılar & Ölçek Sıras1 & Ölçek Değeri \\
Problemi Belirleme & U1 & 3 & 0,303 \\
Değişkenleri Belirleme & U2 & 7 & 0,535 \\
Literatür Tarama & U3 & 2 & 0,264 \\
Araştırma Yöntemini Belirleme & U4 & 4 & 0,380 \\
Veri Toplama & U5 & 1 & 0,000 \\
Veri Analizi & U6 & 5 & 0,388 \\
Raporlaştırma & U7 & 6 & 0,423 \\
\hline
\end{tabular}

Tablo 3 incelendiğinde Türkçe öğretmenliği programı öğretmen adaylarının bilimsel araştırma becerilerine yönelik öz yeterlik algılarının veri toplama uyarıcısının en yüksek ve değişkenleri belirleme uyarıcısının ise en düşük olduğu görülmektedir. Öğretmen adaylarının bilimsel araştırma becerilerine yönelik öz yeterlik algılarının en yüksek olandan en düşük olana doğru ölçek sıralarının veri toplama, literatür tarama, problemi belirleme, araştırma yöntemini belirleme, veri analizi, raporlaştırma ve değişkenleri belirleme olduğu sonucuna ulaşılmıştır.

$\mathrm{Bu}$ çalışmada öğrenim görülen program türünün, araştırma yeterliği bakımından farklılaştığ1 sonucuna ulaşmıştır. Diğer taraftan Büyüköztürk (1996), çalışmasında araştırma yeterliğinin, öğrenim görülen alana göre farklılaşmadığı sonucuna ulaşmıştır. Bu bulgu, Büyüköztürk'ün (1996) bulgusuyla farklılık göstermektedir.

İlköğretim Matematik Öğretmenliği Programı öğretmen adayları için bilimsel araştırma becerilerine yönelik öz yeterlik algılarına ilişkin ölçek değerleri Tablo 4'te verilmiştir.

Tablo 4. Illköğretim Matematik Öğretmenliği Programı Öğretmen Adaylarının Bilimsel Araştırma Becerilerine Yönelik Öz Yeterlik Algllarına İlişkin Ölçek Değerleri

\begin{tabular}{lccc}
\hline Faktörler & Uyarıcılar & Ölçek Sırası & Ölçek Değeri \\
Problemi Belirleme & U1 & 1 & 0,000 \\
Değişkenleri Belirleme & U2 & 6 & 0,457 \\
Literatür Tarama & U3 & 3 & 0,383 \\
Araştırma Yöntemini Belirleme & U4 & 4 & 0,424 \\
Veri Toplama & U5 & 2 & 0,242 \\
Veri Analizi & U6 & 7 & 0,543 \\
Raporlaştırma & U7 & 5 & 0,438 \\
\hline
\end{tabular}

Tablo 4 incelendiğinde ilköğretim matematik öğretmenliği programı öğretmen adaylarının bilimsel araştırma becerilerine yönelik öz yeterlik algılarının problemi belirleme uyarıcısının en yüksek ve veri analizi uyarıcısının ise en düşük olduğu görülmektedir. Öğretmen adaylarının bilimsel araştırma becerilerine yönelik öz yeterlik algılarının en yüksek olandan en düşük olana doğru ölçek sıralarının problemi belirleme, veri toplama, literatür 
tarama, araştırma yöntemini belirleme, raporlaştırma, değişkenleri belirleme ve veri analizi olduğu sonucuna ulaşılmıştır.

Devlet üniversitesinde öğrenim gören öğretmen adayları için bilimsel araştırma becerilerine yönelik öz yeterlik algılarına ilişkin ölçek değerleri Tablo 5’te verilmiştir.

Tablo 5. Devlet Üniversitesinde Öğrenim Gören Öğretmen Adaylarının Bilimsel Araştırma Becerilerine Yönelik Öz Yeterlik Algllarına İlişkin Ölçek Değerleri

\begin{tabular}{lccc}
\hline Faktörler & Uyarıcılar & Ölçek Sırası & Ölçek Değeri \\
Problemi Belirleme & U1 & 2 & 0,642 \\
Değişkenleri Belirleme & U2 & 5 & 1,027 \\
Literatür Tarama & U3 & 3 & 0,845 \\
Araştırma Yöntemini Belirleme & U4 & 6 & 1,319 \\
Veri Toplama & U5 & 4 & 0,938 \\
Veri Analizi & U6 & 7 & 1,443 \\
Raporlaştırma & U7 & 1 & 0,000 \\
\hline
\end{tabular}

Tablo 5 incelendiğinde devlet üniversitesinde öğrenim gören öğretmen adaylarının bilimsel araştırma becerilerine yönelik öz yeterlik algılarının raporlaştırma uyarıcısının en yüksek ve veri analizi uyarıcısının ise en düşük olduğu görülmektedir. Öğretmen adaylarının bilimsel araştırma becerilerine yönelik öz yeterlik algılarının en yüksek olandan en düşük olana doğru ölçek sıralarının raporlaştırma, problemi belirleme, literatür tarama, veri toplama, değişkenleri belirleme, araştırma yöntemini belirleme ve veri analizi olduğu sonucuna ulaşılmıştır.

Vakıf üniversitesinde öğrenim gören öğretmen adayları için bilimsel araştırma becerilerine yönelik öz yeterlik algılarına ilişkin ölçek değerleri Tablo 6'da verilmiştir.

Tablo 6. Vakı Üniversitesinde Öğrenim Gören Öğretmen Adaylarının Bilimsel Araştırma Becerilerine Yönelik Öz Yeterlik Algılarına İlişkin Ölçek Değerleri

\begin{tabular}{llcl}
\hline Faktörler & Uyarıcılar & Ölçek Sıras1 & Ölçek Değeri \\
Problemi Belirleme & U1 & 2 & 0,146 \\
Değişkenleri Belirleme & U2 & 7 & 0,422 \\
Literatür Tarama & U3 & 3 & 0,225 \\
Araştırma Yöntemini Belirleme & U4 & 4 & 0,312 \\
Veri Toplama & U5 & 1 & 0,000 \\
Veri Analizi & U6 & 6 & 0,359 \\
Raporlaştırma & U7 & 5 & 0,351 \\
\hline
\end{tabular}

Tablo 6 incelendiğinde vakıf üniversitesinde öğrenim gören öğretmen adaylarının bilimsel araştırma becerilerine yönelik öz yeterlik algılarının veri toplama uyarıcısının en yüksek ve değişkenleri belirleme uyarıcısının ise en düşük olduğu görülmektedir. Öğretmen adaylarının bilimsel araştırma becerilerine yönelik öz yeterlik algılarının en yüksek olandan en düşük olana doğru ölçek sıralarının veri toplama, problemi belirleme, literatür tarama, araştırma yöntemini belirleme, raporlaştırma, veri analizi ve değişkenleri belirleme olduğu sonucuna ulaşılmıştır. Bu çalışmada araştırma yeterliğinin üniversitelere göre farklılık gösterdiği sonucuna ulaşılmıştır. Bu bulgu Büyüköztürk'ün (1996) araştırma bulgusuyla örtüşmektedir.

Kadın öğretmen adayları için bilimsel araştırma becerilerine yönelik öz yeterlik algılarına ilişkin ölçek değerleri Tablo 7'de verilmiştir. 
Tablo 7. Kadın Öğretmen Adaylarının Bilimsel Araştırma Becerilerine Yönelik Öz Yeterlik Algılarına İlişkin Ölçek Değerleri

\begin{tabular}{llcl}
\hline Faktörler & Uyarıcılar & Ölçek Sıras1 & Ölçek Değeri \\
Problemi Belirleme & U1 & 3 & 0,086 \\
Değişkenleri Belirleme & U2 & 5 & 0,254 \\
Literatür Tarama & U3 & 2 & 0,020 \\
Araştırma Yöntemini Belirleme & U4 & 6 & 0,289 \\
Veri Toplama & U5 & 1 & 0,000 \\
Veri Analizi & U6 & 7 & 0,538 \\
Raporlaştırma & U7 & 4 & 0,164 \\
\hline
\end{tabular}

Tablo 7 incelendiğinde kadın öğretmen adaylarının bilimsel araştırma becerilerine yönelik öz yeterlik algılarının veri toplama uyarıcısının en yüksek ve veri analizi uyarıcısının ise en düşük olduğu görülmektedir. Öğretmen adaylarının bilimsel araştırma becerilerine yönelik öz yeterlik algılarının en yüksek olandan en düşük olana doğru ölçek sıralarının veri toplama, literatür tarama, problemi belirleme, raporlaştırma, değişkenleri belirleme, araştırma yöntemini belirleme ve veri analizi olduğu sonucuna ulaşılmıştır.

$\mathrm{Bu}$ çalışmada kadın öğretmen adaylarının veri analizi uyarıcısının son sırada olması, onların öz yeterlik algılarının düşük olduğunu göstermektedir. Bu bulgu Winans ve Madhava'nın (1992), bulgusu ile paralellik göstermektedir. Winans ve Madhavan'a (1992) göre, araştırma yeterliğine ilişkin güven duygusu yüksek olan üniversiteli gençlerin başarılarının yüksek olduğu ancak kız öğrencilerin güven duygusunun, erkek öğrencilerin güven duygusundan anlamlı derecede düşük olmaktadır.

Erkek Öğretmen adayları için bilimsel araştırma becerilerine yönelik öz yeterlik algılarına ilişkin ölçek değerleri Tablo 8'de verilmiştir.

Tablo 8. Erkek Ögretmen Adaylarının Bilimsel Araştırma Becerilerine Yönelik Öz Yeterlik Algılarına İlişkin Ölçek Değerleri

\begin{tabular}{llcl}
\hline Faktörler & Uyarıcılar & Ölçek Sıras1 & Ölçek Değeri \\
Problemi Belirleme & U1 & 5 & 0,288 \\
Değişkenleri Belirleme & U2 & 7 & 0,445 \\
Literatür Tarama & U3 & 3 & 0,186 \\
Araştırma Yöntemini Belirleme & U4 & 6 & 0,396 \\
Veri Toplama & U5 & 2 & 0,097 \\
Veri Analizi & U6 & 4 & 0,287 \\
Raporlaştırma & U7 & 1 & 0,000 \\
\hline
\end{tabular}

Tablo 8 incelendiğinde erkek öğretmen adaylarının bilimsel araştırma becerilerine yönelik öz yeterlik algılarının raporlaştırma uyarıcısının en yüksek ve değişskenleri belirleme uyarıcısının ise en düşük olduğu görülmektedir. Öğretmen adaylarının bilimsel araştırma becerilerine yönelik öz yeterlik algılarının en yüksek olandan en düşük olana doğru ölçek sıralarının raporlaştırma, veri toplama, literatür tarama, veri analizi, problemi belirleme, araştırma yöntemini belirleme ve değişkenleri belirleme olduğu sonucuna ulaşılmıştır.

$\mathrm{Bu}$ araştırmadaki bulgular, Gündoğdu'nun (2001) bulgularıyla benzerlik göstermektedir. Gündoğdu'ya (2001) göre bilimsel düşünme becerisi ile eğitim sürecinin ilişkisini inceleyen çalışmalar, eğitim sürecinin bilimsel düşünme becerisinin gelişiminde belirleyici bir öneme sahip olduğunu göstermektedir. Akademik yaşamda erkeklerde bazı derslerde kızlardan daha başarılı olacağı konusundaki önyargıları destekler şekilde gözlenen 
matematik başarısının çoğu kez cinsiyete göre değişmesi cinsiyet rollerindeki ayrımın ne kadar belirleyici olabileceğinin tipik bir örneğidir. Eğitimin cinsiyet farklılıkları açısından iki boyutta ele alınmaktadır.İlk boyutta, cinsel rollerin öğrenildiği veya cinsiyet sosyalizasyonunun gerçekleştiği en önemli toplumsal kurumlardan birisi olarak okulların olduğu ve ikinci boyutta ise eğitimde kadınlar aleyhine bir firsat eşitsizliğinin olduğu gerçeğidir. Bu bakımdan kızlar ve erkekler farklı çevrelerde yaşadıkça farklı iki kültür geliştirmekte; farklı çevrelerde yaşayan bu iki cinsiyet, farklı davranış örüntüleri, farklı zevkler, farklı duygusal özellikler, farklı beceriler ve farklı düşünme biçimlerini göstermektedirler. $\mathrm{Bu}$ nedenle cinsel rollerdeki farklılıklar ise ister doğuştan getirilmiş ve genetik etkenlerin sonucunda ortaya çıkmış olsun ister toplumsallaşma sürecinde aile, arkadaş çevresi ve okul gibi çevrelerde ögrenilmiş olsun değişik cinsiyet rolündeki bireylerin davranışlarında bir fark bulunmaktadır.

Tüm grup için öğretmen adaylarının bilimsel araştırma becerilerine yönelik öz yeterlik algılarına ilişkin ölçek değerleri Tablo 9'da verilmiştir.

Tablo 9. Tüm Grup Için Öğretmen Adaylarının Bilimsel Araştırma Becerilerine Yönelik Öz Yeterlik Algılarına İlişkin Ölçek Değerleri

\begin{tabular}{lccc}
\hline Faktörler & Uyarıcılar & Ölçek Sırası & Ölçek Değeri \\
Problemi Belirleme & U1 & 4 & 0,112 \\
Değişkenleri Belirleme & U2 & 6 & 0,294 \\
Literatür Tarama & U3 & 2 & 0,055 \\
Araştırma Yöntemini Belirleme & U4 & 5 & 0,284 \\
Veri Toplama & U5 & 1 & 0,000 \\
Veri Analizi & U6 & 7 & 0,431 \\
Raporlaştırma & U7 & 3 & 0,091 \\
\hline
\end{tabular}

Tablo 9 incelendiğinde tüm grup için öğretmen adaylarının bilimsel araştırma becerilerine yönelik öz yeterlik algılarının veri toplama uyarıcısının en yüksek ve veri analizi uyarıcısının ise en düşük olduğu görülmektedir. Öğretmen adaylarının bilimsel araştırma becerilerine yönelik öz yeterlik algılarının en yüksek olandan en düşük olana doğru ölçek sıralarının veri toplama, literatür tarama, raporlaştırma, problemi belirleme, araştırma yöntemini belirleme, değişkenleri belirleme ve veri analizi olduğu sonucuna ulaşılmıştır.

$\mathrm{Bu}$ çalışmada tüm grup için veri analizi uyarıcısının en düşük olduğu görülmektedir. Bunu sırasıyla değişkenleri ve araştırma yöntemlerini belirleme uyarıcıları izlemektedir. Dolayısıyla öğretmen adaylarının bilimsel araştırma becerilerine yönelik öz yeterlik algılarının düşük ve yetersiz olduğu sonucuna ulaşılmıştır. Bu bulgu Büyüköztürk'ün (1996) ve Karagül'ün (1996) bulguları ile örtüşmektedir. Büyüköztürk (1996) ve Karagül (1996), üniversite öğrencilerinin araştırma yeterliklerine sahip olma düzeyini yetersiz bulmuşlardır. Benzer şekilde Nartgün, Uluman, Akın, Çelik, Çevik, Şanlı ve Gülözer (2008), çalışmalarında araştırma teknikleri dersini alan öğretmen adaylarının araştırmaya yönelik öz yeterlik algılarının araştırma teknikleri dersini almayan öğretmen adaylarından daha yüksek olduğunu belirlemişlerdir. $\mathrm{Bu}$ şekilde araştırma yöntemleri dersi almanın öğretmen adaylarının öz yeterlik algılarını geliştirdiği ifade edilebilir.

\section{SONUÇLAR ve TARTISMMA}

$\mathrm{Bu}$ araştırma lisans düzeyinde öğrenim gören ve bilimsel araştırma yöntemleri dersi almış öğretmen adaylarının, bilimsel araştırma becerilerine ilişkin öz yeterlik algıları ile ilişkili olduğu düşünülen faktörlerin ikili karşılaştırmalar kanunu ile V.hal denkleminden tam veri matrisinden ölçeklenmesini konu edinmektedir. Bilimsel araştırma becerilerine ilişkin öz 
yeterlik algıları ile ilişkili olduğu düşünülen faktörler, "öğrenim görülen program, devlet ya da vakıf üniversitesinde öğrenim görme ve cinsiyet" değişkenlerine göre ölçeklenmiştir.

Araştırmanın bulguları neticesinde öğretmen adaylarının bilimsel araştırma becerilerine ilişkin öz yeterlik algılarına yönelik elde edilen ölçek değerleri incelendiğinde genel olarak veri toplama ve raporlaştırma niteliklerinin en yüksek; veri analizi ve değişkenleri belirleme niteliklerinin ise en düşük yeterliğe sahip özellikler olduğu sonucuna ulaşılmıştır. Bu durumda öğretmen adayları veri toplama ve raporlaştırma becerilerini kazandıkları ancak değişkenleri belirlemede sıkıntı yaşamaları nedeni ile verileri analiz etmede güçlük çektikleri sonucuna varılmıştır.

$\mathrm{Bu}$ çalışmada öğretmen adaylarının bilimsel araştırma becerilerine ilişkin öz yeterlik algıları üzerinde etkili olduğu düşünülen faktörler ikili karşılaştırmalar kanunu ile ölçeklenmiştir. Diğer ölçekleme yöntemleri kullanılarak benzer bir çalışma yapılabilir. Ayrıca bu faktörler, "öğrenim görülen program, üniversite türü ve cinsiyet” değişkenlerine göre incelenmiştir. İlgili faktörler, bağımsız değişken sayısı artırılarak ya da daha farklı değişkenler ele alınarak araştırılabilir.

\section{KAYNAKLAR}

Anıl, D. ve Güler, N. (2006). İkili karşılaştırma yöntemiyle ölçekleme çalışmasına bir örnek. Hacettepe Üniversitesi Eğitim Fakültesi Dergisi, 30, 30-36.

Bandura, A. (1997). Self-efficacy: The exercise of control. New York: W.H.Freeman Publishers.

Bieschke, K. J., Bishop, R. M., ve Garcia, V. L. (1996). The utility of the research self- efficacy scale. Journal of Career Assessment, 4, 59-75.

Büyüköztürk, Ş. (1996). Türk yüksek öğretiminde araştırma eğitimi. Yayınlanmamış Doktora Tezi. Ankara Üniversitesi Sosyal Bilimler Enstitüsü. Ankara.

Büyüköztürk, Ş. (1999). Araştırmaya yönelik kaygı ile cinsiyet, araştırma deneyimi ve araştırma başarısı arasındaki ilişki. Ĕgitim ve Bilim. 23, 29-34.

Büyüköztürk, Ş. ve Köklü, N. (1999). Eğitim bilimleri alanında öğrenim gören lisansüstü öğrencilerin araştırma yeterlikleri konusunda öğretim üyelerinin görüşleri. Eğitim ve Bilim, 23 (112), 18-23.

Chiappetta, E.\& Russel, J. M. (1982). The relationship among logical thinking, problem solving instruction and knowledge and application of earth science subject matter. Science Education. 66, 1, 85-93.

Crocker, L. ve Algina J. (1986). Introduction to classical and modern test theory. Orlando: Harcourt Brace Jovanovich Inc.

Godson, I.(1994).Studying teacher's life and work. Teaching and Teachers Education.10(1),29-37, January.

Geban, Ö. (1990). Effects of Two Different Instructional Treatments on the Students' Chemistry Achievement, Science Process Skills and Attitude towards Chemistry at the High School Level. Yayınlanmamış Doktora Tezi, ODTU, Ankara.

Green, K., ve Kvidhal, R. (1990). Research methods courses and post-bachelor's education: Effects on teachers' use and opinions. Paper presented at the Annual Meeting of the American Educational Research Association, Boston, MA. (ERIC Document Reproduction Service No. ED320881)

Guilford, J.P. (1954). Psychometrics methods. (2nd ed). New York: McGraw-Hill Book.

Guskey, T.R. \&Passaro, P. (1994). Teacher efficacy: A study of construct dimensions. American Educational Research Journal, 31 (3), 627-643.

Gündoğdu, M. (2001). Üniversite ögrrencilerinin bilimsel düşünme becerilerinin yordanmasi. Hacettepe Üniversitesi, Sosyal Bilimler Enstitüsü, Yayınlanmamış Doktora Tezi, Ankara.

Kaptan, S. (1995). Bilimsel Araştırma Teknikleri. (2.Basım). Ankara:Hacettepe Üniversitesi Yayınları.

Karagül, T. (1996). Yükseköğretim programlar iç̧in gerekli öğrenci yeterlikleri ve yükseköğrenime geçiş süreci. Ankara Üniversitesi Sosyal Bilimler Enstitüsü, Yayınlanmamış Doktora Tezi, Ankara.

Karasar, N. (2002). Bilimsel araştırma yöntemi (2. Bask1). Ankara: Nobel Yayınları

Nartgün, Z., Uluman, M., Akın, Ç., Çelik, T.Çevik, C., Şanl, H.Gülözer, A. (2008). Öğretmen $\quad$ Adaylarının bilimsel araştırma öz yeterliklerinin incelenmesi. 17. Eğitim Bilimleri Kongresi. 1-3 Eylül 2008, Sakarya Üniversitesi.

Phillips, J. C. ve Russell, R. K. (1994). Research self-efficacy, the research-training envirment and the student in counseling psychology: Does the research training environment influence graduate students' attitudes toward research? The Counseling Psychologist, 14, 9-30. 
Rifkin, T. \& Georgakakos, J.H.(1996). Science reasoning ability of community college students. ERIC No:ED393505.

Saracaloglu, A. S., Varol, R. ve Evin, İ. (2003). Lisansüstü eğitim öğrencilerinin bilimsel araştırma kayglları, araştırma ve istatistiğe yönelik tutumları ile araştırma yeterlikleri arasındaki ilişki. E Eğitimde Bilime Katkl. Lisansüstü Eğitim Sempozyumu. Dokuz Eylül Üniversitesi Eğitim Bilimleri Enstitüsü. 1-4 Ekim 2003. İzmir.

Stevens, S. S. (1946). On the theory of scales of measurement. Science, 103, 677-680.

Stuessy, C. (1984). Correlates of scientific reasoning in adolescents: Experience, locus of control, age, field, dependence-independence, Rigidity/Fkexibility, IQ and Gender. ERIC No: ED244 834.

Turgut, M. F. ve Baykul, Y. (1992-1). Ölçekleme teknikleri. Ankara: ÖSYM Yayınları

Torgerson, W. S. (1958). Theory and methods of scaling. Newyork: John Wiley \& Sons Inc.

Unrau, Y.A. ve Beck, A.R. (2004). Increasing research self-efficacy among students in professional academic programs. Innovative Higher Education. 28(3), 187-204.

Winans, K.S. \& Madhavan, S. (1992). Some factors influencing undergraduate pharmacy students' perception of and attitudes toward research related activities. American Journal of Pharmaceutical Education. 56(1), 29-35.

\section{EXTENDED ABSTRACT}

\section{Introduction}

The main purpose of the research is to determine prospective teachers' self efficacy perceptions regarding their research skills by scaling from the full data matrix through the pair-wise comparison method. Prospective teachers' self efficacy perceptions regarding their research skills were determined in terms of three variables - the teaching program, type of university and sex.

\section{Method}

In the present study, it was aimed to determine prospective teachers' self efficacy perceptions regarding their research skills by scaling through the pair-wise comparison method. Since it wasn't aimed to make a generalization from the sample to the population in this study, this study is a basic quantitative research model (Karasar, 2002). In a scientific research process, "research methods, statistics, measurement and evaluation and computer fields" are the components of research competencies (Büyüköztürk \& Köklü, 1999). For this reason, the scientific research steps such as "determination of problem, literature review, data collection, data analysis and reporting" were taken into consideration in the preparation of measurement instrument. In the present study, these qualifications regarding research skills of each prospective teacher were ranked through the pair-wise comparisons and then frequency matrice (F matrice) was formed. Then, the value in each cell in the frequency matrice was divided by the total number of people $(\mathrm{N})$ and "the rates matrice" ( $\mathrm{P}$ rates matrice) was achieved. The standard values corresponding to the values in each cell in the "rates matrice" were determined. Then, " $Z$ unit normal deviations matrice" was achieved and scale values were computed. By the determination of one or more than one negative scale value, the minimum value was equated to zero. In other words, the point of origin was moved to zero and all scale values were iterated so as to be positive.

\section{Results and Discussion}

In this part, frequency matrice was formed for the variables "teaching program, type of university and sex". Then "the rates matrice" was formed based on frequency matrice. And then, " $Z$ unit normal deviations matrice" and "differences matrice" were formed. Finally, the "error statistics" were computed and the findings were interpreted below. For the prospective "guidance and counseling" teachers, of their self efficacy perceptions regarding their research skills, the stimulus of "literature review" was determined to be the highest while the stimulus of "data analysis" was determined to be the lowest. For the prospective "social sciences" teachers, the stimulus of "reporting" was determined to be the highest while the stimulus of "determination of variables" was determined to be the lowest. For the prospective "Turkish" teachers, the stimulus of "data collection" was determined to be highest while the stimulus of 
"determination of variables" was determined to be the lowest. For the prospective "elementary mathematics" teachers, the stimulus of "determination of problem" was determined to be the highest while the stimulus of "data analysis" was determined to be the lowest. For the prospective teachers who study in the state universities, the stimulus of "reporting" was determined to be the highest while the stimulus of "data analysis" was determined to be the lowest. For the prospective teachers who study in the foundations universities, the stimulus of "data collection" was determined to be the highest while the stimulus of "determination of variables" was determined to be the lowest. For the female prospective teachers, the stimulus of "data analysis" was determined to be the highest while the stimulus of "data analysis" was determined to be the lowest. For the male prospective teachers, the stimulus of "reporting" was determined to be the highest while the stimulus of "determination of variables" was determined to be the lowest. For all the prospective teachers, the stimulus of "data collection" was determined to be the highest while the stimulus of "data analysis" was determined to be the lowest. When the scale values related to prospective teachers' self efficacy perceptions regarding their research skills were examined, the qualifications "data collection" and "reporting" were determined to be the highest while the qualifications "data analysis" and the "determination of variables" were determined to be the lowest. As a result, it might be stated that prospective teachers have gained the skills "data collection and reporting" but they have difficulty with data analysis because of the fact that they have difficulty with determining the variables. 